\title{
CATEGORIZATION OF BUSINESS SUBJECTS: MODERN APPROACHES AND TRENDS IN THE WORLD AND IN UKRAINE
}

\author{
Igor Pandyak \\ Ivan Franko National University of Lviv, \\ P. Doroshenko St., 41, UA - 79007 Lviv, Ukraine, \\ e-mail: pandyakig@ukr.net
}

The study focuses on the relevance of categorization in the management of the quality of service of hotel enterprises. The main approaches to categorization of hotel business actors in the world and in Ukraine have been analyzed, attention has been paid to the need to define key concepts in the management of the quality of the placement service, the issues of standards and the current categorization process in Ukraine, the direction of their solution has been substantiated.

The spatial organization of categorized hotel enterprises in Ukraine was analyzed, and the dependence of the share with the rating and structure of the star categories on the tourist attractiveness of the regions was determined. The international and Ukrainian hotel corporations, whose enterprises are all categorized in a high segment, have a significant influence on the categorization.

Among the main issues of categorization in Ukraine are as follows: obsolete, not appropriate current requirements regarding the quality of the service of regulations, complicated procedure of categorization, absence of a legal mechanism of influence on hotel enterprises, which publicly declare a certain category without passing the categorization process, unequal regulatory requirements for the passage of categorization the subjects of the hotel business of different legal form, capacity, historical status of the building, not formed in the majority of investors, top management, hotel business, professional consciousness that needs to be taken globally.

Key words: hotel business subjects, categorization, certification, classification, standards, quality of service, categorization systems, normative-legal support.

One of the main issues of the hotel business' organization is the management of service's quality. The hotel enterprise's category makes the complex of characteristics of the service's quality and informs the interested sides of the market about them in the hospitality market. At the same time, there is an unresolved issue of the standards' unification and approaches of the rating of hotel enterprises in the world. The difficulty is growing with the spreading not only traditional categorization systems but also unconventional categorization systems driven by technical and informational progress and also significant diversification of types of hotel enterprises.

The issue of categorization is especially topical in Ukraine. The inconsistency of categorization's system of hotel enterprises has led to formal character of the process itself, the significant abuse of rating by the subjects of the hotel business and discontent of consumers of services in the market of services in the state. However, the categorization problem of hotel

(C) Pandyak I., 2019

\section{¿ Open Access}

(сc) ВY публічної ліцензії Creative Commons "Із зазначенням авторства -4.0 міжнародна" 
enterprises is inherent in the global character, it is complex and multidimensional, needs to be studied and to be recommended for resolution.

The management of the service's quality in the system of categorization and certification of hotel enterprises has been analyzed in the works of Ukrainian and foreign scientists: I. Biletska [8], M. Malska, I. Pandyak [10, 11], T. Grin'ko, I. Timar [5, 8], T. Tkachenko [13], V. Fedorchenko [14], A. Israel, N. Uriely [2], R. Minazzi [3] etc.

For the consumers, the categorization is a means of informing about the quality of services by providers of hotel services. However, their level of satisfaction doesn't depend on the category of a hotel facility, but on providing the consumers' expectations. The main problem of categorization is the fact of comparing the received information by a potential guest about the enterprise or about the previous experience of using the hotel with the actual quality of service at the time of receipt. It is necessary to provide the customers' adherence by providing the customers' pleasure to the subject of hotel business, so the service conformity of declared category of a hotel enterprise in corresponding services.

The analysis of world experience and development's trends in the categorization of hotel enterprises shows that there is no unified categorization system, unified approaches, criteria and procedures. Nowadays, in most researches is mechanically emphasized on the existence of about thirty categorization systems used in different countries of the world. The symbolism of this statement is in an attempt to focus on a large number of systems, which are expressed in used categorization symbols by regions, states (stars, crowns, diamonds, letters, keys etc.). However, different categorization systems were formed even within the same system in each country, due to its cultural identity.

Nowadays, the specialists of studies of issues in the management of the service's quality of hotel focus on the study of marketing technologies for hotel business. The marketing system covers various activities, such as categorization, service standards, and also such important areas as the image and brand of hotel enterprises. The image is the formation of an idea about an enterprise that is based on a personal experience and the received information about its actual, declared and expected quality, the characteristics and indicators which are important for economic, social and another value for the interaction subjects [9].

The categorization is official and optional in Ukraine today, the rating of the hotel is marked with a "star", the process is carried out itself by a specially authorized state body.

Of the 4,115 collective accommodation facilities, as of April 2019, 252 (6.1\%) were categorized, including 2 sanatoriums. The regional imbalances in the development of infrastructure for the placement are also reflected in the number of categorized hotel establishments. Nearly $55 \%$ are located in the most attractive regions for tourists (66 enterprises in the Kyiv region, 46 in Odesa region, 29 in Lviv region) of all categorized enterprises. $26(0.6 \%)$ are located in rural areas of all categorized enterprises.

An extremely low level of categorization of hotel enterprises in Ukraine reflects the problems of management of the tourism field, the quality of goods and services. The problem is complex, the main precondition of which is the lack of attention to the industry and as a result are the obsolete and the imperfect legislative and regulatory framework, the contradiction and mutual denial of key provisions on the mandatory categorization, the lack of development of non-state profile organizations, and therefore there is almost no influence of authoritative expert agencies which are developed in many countries, such as Switzerland, Germany, the USA, Great Britain and others $[1,4]$. 
The distribution of categorized subjects of the hotel business is characterized by significant differences within the territory of Ukraine. There is no categorized accommodation establishment in Luhansk region. A low part of the star hotels are traditionally located in Volyn, Transcarpathia, Zaporizhia, Kropyvnytskyi, Mykolaiv, Kherson, Cherkasy, Chernivtsi regions. The largest part of categorized hotels from the total number of enterprises are in Kyiv region (including Kyiv), Odesa and Lviv regions and they are the most attractive for tourists. More than half $(54,8 \%)$ of the categorized hotels are located in these regions of Ukraine.

In the structure of the categorized hotels, the highest proportion of subjects of average and above average service level - three or four stars (more than $70 \%$ ) are the most popular in that business. There is a low proportion of the categorized hotels with "one star" $-6.7 \%$, because of the small attractiveness of this category, and the "five stars" - $11.9 \%$, because they are designed for a narrow segment of clients.

The largest number of the categorized hotels in the segment "three-five stars" are in Kyiv, Odesa and Lviv regions, these regions are with the largest number of visits by foreign tourists. Odessa region is the leader in Ukraine in terms of the number of high-class hotels. There are no such high-class hotels in Donetsk, Kropyvnytskyi, Mykolaiv, Kherson regions (see table). Up to $20 \%$ belongs to law-abiding international and Ukrainian hotel corporations, among the categorized hotels, which are positioned in the category of "four stars" and "five stars", several hotels in the category "three stars". A categorization is one of the most important components of the image among the international hotel groups, like "Raddisson Hyatt Hotels Corporation", "Hilton Hotels \& Resorts", "Rixos Hotels", "Wyndham Hotel Group (Ramada)" and others. The Ukrainian corporations are organised by the similar principal - "Premier Hotels and Resorts" (four to five stars), "Reikartz Hotel Group" (three or four stars), which are well-known because of the quality of service.

The main standard whereby the procedure of categorization is carried out is DSTU (National Standard of Ukraine) 4269:2003 "Touristic services. Classification of hotels" [2] is outdated and does not meet the hotel services' requirements of Ukraine and EU countries which standards are corrected every six years. The basic notes about this standard are:

- Requirements for the obligatory passage of hotels categorization. Nowadays whereby the Law "On Tourism" of Ukraine [11] the categorization is compulsory, but it is carried out on the basis of freewill certification. The term "categorization" is not used in our legislation, so that we have to take as synonyms the concept of "categorization" and the concept of "certification". However, procedural certification is the accordance of the hotel construction with the technical characteristics with regard to the safety of life and health of people, the protection of their property and environment preservation, that is set at the stage of getting the building in the exploitation [13]. Instead, the "categorization" of hotels enterprises is the process of assigning a hotel to a certain class not only according to material, technical and protection components of the hotel building, but also including a complex of components of service quality, among which a special role goes to a professional staff, service technology, matching the level of acceptable standards of quality, profiled professional organization. The hotel's category has to be a mark for clients, to show the expectable comfort not only for Ukrainian guests but also for foreign customers, so meet international standards.

- Complicated procedure of passaging of categorization. Regional certification and metrology centers conduct the certification due to which conclusions the Commission of the Ministry of Economic Development and Trade of Ukraine establishes the category of hotel enterprises, they issue a certificate about the assignment of a certain category. The positive moment is that the 
certificate is given for the insignificant term for three or five years, so it prompts the hotels' enterprises maintain a stable quality of service during the standby mode.

Categorization of collective accommodation facilities in Ukraine, April 2019

Категоризація колективних засобів розміщення в Україні, квітень 2019 р.

\begin{tabular}{|c|c|c|c|c|c|c|c|c|c|}
\hline \multirow{2}{*}{ № } & \multirow{2}{*}{ The region } & \multirow{2}{*}{ 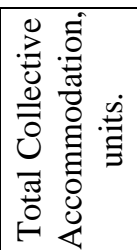 } & \multirow{2}{*}{ 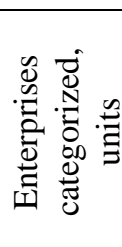 } & \multirow{2}{*}{ 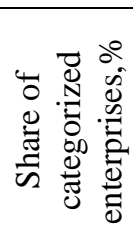 } & \multicolumn{5}{|c|}{ Assigned category } \\
\hline & & & & & 1 star & 2 stars & 3 stars & 4 stars & 5 stars \\
\hline 1 & Crimea & - & - & - & - & - & - & - & - \\
\hline 2 & Vinnytsia & 85 & 3 & 3,5 & - & 1 & 1 & 1 & - \\
\hline 3 & Volyn & 131 & 1 & 0,8 & - & - & 1 & - & - \\
\hline 4 & Dnipropetrovsk & 228 & 19 & 8,3 & 1 & 4 & 7 & 5 & 2 \\
\hline 5 & Donetsk & 121 & 6 & 5,0 & - & 1 & 5 & - & - \\
\hline 6 & Zhytomyr & 80 & 3 & 3,8 & - & - & 1 & 2 & - \\
\hline 7 & Transcarpathian & 250 & 5 & 2,0 & - & - & 2 & 3 & - \\
\hline 8 & Zaporizhia & 374 & 5 & 1,3 & 2 & 1 & 2 & - & - \\
\hline 9 & Ivano-Frankivsk & 274 & 9 & 3,3 & - & - & 6 & 2 & 1 \\
\hline 10 & Kyiv & 162 & 62 & 38,3 & 3 & 7 & 28 & 17 & 7 \\
\hline 11 & Kropyvnytskyi & 46 & 1 & 2,2 & - & - & 1 & - & - \\
\hline 12 & Lugansk & 29 & - & - & - & - & - & - & - \\
\hline 13 & Lviv & 337 & 32 & 9,5 & - & - & 12 & 15 & 5 \\
\hline 14 & Mykolaiv & 271 & 1 & 0,4 & - & - & 1 & - & - \\
\hline 15 & Odesa & 529 & 44 & 8,3 & 5 & 3 & 8 & 15 & 13 \\
\hline 16 & Poltava & 107 & 13 & 12,1 & 2 & 4 & 5 & 2 & - \\
\hline 17 & Rivne & 52 & 3 & 5,8 & 1 & - & 1 & 1 & - \\
\hline 18 & Sumy & 52 & 3 & 5,8 & - & - & 2 & 1 & - \\
\hline 19 & Ternopil & 66 & 5 & 7,6 & - & 1 & 3 & 1 & - \\
\hline 20 & Kharkiv & 175 & 21 & 12,0 & 2 & 1 & 7 & 9 & 2 \\
\hline 21 & Kherson & 225 & 4 & 1,8 & 1 & 2 & 1 & - & - \\
\hline 22 & Khmelnytsky & 90 & 6 & 6,7 & - & 2 & 3 & 1 & - \\
\hline 23 & Cherkasy & 119 & 2 & 1,7 & - & - & 1 & 1 & - \\
\hline 24 & Chernivtsi & 81 & 2 & 2,5 & - & 1 & - & 1 & - \\
\hline 25 & Chernihiv & 49 & 2 & 4,1 & - & - & - & 2 & - \\
\hline 26 & Ukraine & 4115 & 252 & 6,1 & 17 & 28 & 98 & 79 & 30 \\
\hline
\end{tabular}

It is made in accordance with: The Register of certificates of categorization of hotels and other objects intended for the provision of temporary accommodation services (residence) issued by the Ministry of Economic Development and Trade of Ukraine as of 3 April 2019.

- The absence of a legal mechanism of influence on hotel enterprises, which publicly declare a certain category without passing the process of categorization. According to the results of the 
research, nearly $80 \%$ of $94 \%$ of ukrainian hotels abuse the category, which are not even categorized.

- The unequal regulatory requirements about passaging of categorization the subjects of the hotel business of different legal forms, capacity, historical status of the building. According to the standards of DSTU (National Standard of Ukraine) 4269:2003 "Touristic service. Classification of hotels" [12] compulsory categorization for hotels and similar placements' means of legal entities, hotels in old buildings, which are considered as historical and cultural sights, they used to be the subjects for planning changes because of the reconstruction, however they do not still subject to categorization.

- The outdated, do not meet modern requirements for the quality of service by the provision of the Order. For instance, the requirement for availability of radio outlets, color TV in each room in three-five stars hotels and TV with remote control in four-five stars hotels. It is not indicated about flat-screen TVs that use the Internet and others components of information and technological progress which are outdated morally at all. It is not mentioned about using the wireless Internet connection, the lock systems with electronic keys, electronic cashless payment systems and other standards provision for quality service in a lot of ukrainian hotels and generally accepted in foreign standards.

- The subjective nature of individual provisions of the Order, impossibility evaluate numerically certain criterias ("making the hospitality atmosphere by the staff", "the staff have to fulfill the guests' requests actively"), which lead to unreasonable demands, the corruption mechanisms in assessing the quality of hotel services by checking state comissions.

- The list of requirements for categorization is formed from a considerable volume those, which are inappropriate to consider the signs of categorization, but we have to get them as an indispensable condition for the functioning of the hotel business in terms of consumers' demands (the location of the hotel in an ecologically safe area; ensuring life and health of clients, their property, etc.).

Among the organizational problems of categorization there are some such as:

- the absence of effective mechanism of responsible for non-compliance legislative and regulatory requirements; unauthorized assigning a category for a hotel has got widespread;

- most of all without any permissions the hotels get assigned the category of "three-four" stars, due to low attractiveness of hotels with one-two stars and the high customers' requirements for the category of hotels with five stars;

- avoiding the categorization by the hotels shows us the problems in the state tourism policy;

- getting assigned the category by the hotels without any permissions, in conditionals co-use of unofficial ratings which have been formed by customers, experts, hotel chains and other interested parties, shows us not the disregard for the quality of service but a challenge to a modern incapacitated system state categorization and state policy in the Ukrainian touristic field;

- the main subjects' interest of the hotel business to unauthorized categorization in an effort to declare the quality of the service is much higher than the real state;

- the professional consciousness is not formed in most investors, top-managements of hotel business, which we have to get globally. Regardless of the forms organization of categorization in the state installation a certain rating for a hotel facility is just one of the criterias, that do not have full-scale impact on the customer, it is just one of the enterprise's reputation, its self-esteem. Hotel's category is not the way of earning more money, but reflection of the investor's decency [12]. 
Inefficiency of the modern system of the hotel enterprises' categorization in Ukraine is caused by the uncertainty of the state policy in the field of hospitality, the immaturity of the hospitality and tourism market. For the effective use of national hotel facilities, the categorization's systems in making the positive reputation on hospitableness business, we need:

- to determine with the categorization's system on national level: compulsory (non compulsory), official (non official);

- to correct the legislative and normative basis with providing clarity, simplicity, coherence of positions for unambiguous understanding the process of categorization by the subjects of the hotel market;

- to set effective and efficient control system and the subjects' responsibility for the hotel business for non-compliance with the requirements of categorization;

- to correct the categorization requirements with reputable in the world regional ones (for example, with the european "Hotelstars Union"), state-owned categorization systems;

- to prompt the hotel business' subjects for consolidation and development an effective professional categorization system, in general for all hotels either according to the segment of their activity;

- to apply the categorization to all the hotel facilities a certain segment of the business equally, due to specialization irrespective of organizational legal form or capacity.

Categorization hotel enterprises has a formal character in Ukraine, it is organised by the state, it is built on the outdated requirements and irrelevant services for customers. The basic function of quality assurance service is almost lost, the imperfection of the legislative and regulatory framework and the lack of legal mechanisms for controlling the use of hotels by the stars of a certain category is not stimulates the absolute majority of hotels prior to categorization. Among the hotels which fulfill obligatory conditions of conducting economic activity and officially declare their rating are primarily international operators, Ukrainian hotel chains and individual companies for which they receive categories - a sign of decency in business.

At the state level, a clear coordination mechanism needs to be developed in the tourist industry. Obviously, to create conditions for effective development the hotel business need to legislate to develop new ones regulatory and support tools, close to countries with experience effective development of this sphere of the economy. It is also necessary to adjust interaction and clear coordination of work between different ministries and departments of which the regulatory policy in the field of hospitality depends.

\section{СПИСОК ВИКОРИСТАНОЇ ЛІТЕРАТУРИ}

1. American Automobile Association - AAA 2008. Approval requirements \& Diamonds rating guidelines. Lodging.

URL: http://www.aaa.biz/Approved/files/evaluation/diamondguidelinesDec08.pdf

2. Israeli A., Uriely $N$. The impact of star ratings and corporate affiliation on hotel room prices // International Journal of Hospitality and Tourism Research. 2000. Vol. 2 (1). P. 27-36. doi:10.1177/146735840000200107

3. Minazzi R. Hotel Classification Systems: A Comparison of International Case Studies // Economica. 2010. Vol. 6, No 4. P. 64-86.

4. Switzerland: Use of stars to classify hotels: public domain or trademark protected? URL: http://condat.blogspot.com/2011/04/switzerland-use-of-stars-to-classify.html

5. Закон України “Про туризм” № 324/95-вр від 15.09.95 р. та Про внесення змін і доповнень до Закону України “Про туризм” від 18.11.03 р. 
6. ДСТУ 4269:2003. Послуги туристичні; Класифікація готелів / Л. Шишкіна (розроб.). Офіц. вид. К.: Держспоживстандарт України, 2004. III, 13 с.

7. Постанова Кабінету Міністрів України від 29.07.2009 р. № 803 "Про затвердження Порядку встановлення категорій готелям та іншим об'єктам, що призначаються для надання послуг з тимчасового розміщення (проживання)".

URL: https://zakon.rada.gov.ua/laws/show/803-2009-\%D0\%BF

8. Білецька I. M. Національні особливості організації готельної справи у світовій індустрії гостинності // Ефективна економіка. 2015. № 1.

URL: http://www.economy.nayka.com.ua/?op=1\&z=3745

9. Гринько T. В., Тімар I. В. Імідж підприємств сфери послуг: сутність поняття та особливості формування // Збірник наукових праць Черкаського державного технологічного університету. Серія: Економічні науки. 2014. Вип. 38. Ч. І. С. 127-133.

10. Мальська М. П., Пандяк I. Г. Готельний бізнес: теорія та практика: підручн. 2-вид. перероб. та доп. К.: Центр учбової літератури, 2012. 472 с.

11. Пандяк I. Історія категоризації готельних підприємств в Україні // Географія, економіка і туризм: національний та міжнародний досвід: матеріали IX наук. конф. 3 міжнар. участю. Львів: Вид. центр ЛНУ ім. Івана Франка, 2015. С. 146-152.

12. Tiмар I. B. Категоризація підприємств готельного бізнесу: вітчизняний та світовий досвід // Управління розвитком. 2016. № 3. С. 71-77.

13. Ткаченко T. Управление качеством гостинничных услуг // Гостинничный бизнес. 2005. № 4. C. 24-27.

14. Федорченко В. К., Мініч I. М. Готельне господарство: основні показники, оцінка якості послуг. К.: КУТЕП, 1999. 78 с.

\section{REFERENCES}

1. American Automobile Association - AAA 2008. Approval requirements \& Diamonds rating guidelines. Lodging.

URL: http://www.aaa.biz/Approved/files/evaluation/diamondguidelinesDec08.pdf

2. Israeli, A. A., \& Uriely, N. (2000). The Impact of Star Ratings and Corporate Affiliation on Hotel Room Prices in Israel. Tourism and Hospitality Research, 2(1), 27-36. doi:10.1177/146735840000200107

3. Minazzi, R. (2010). Hotel Classification Systems: A Comparison of International Case Studies. Economica, 6(4), 64-86.

4. Switzerland: Use of stars to classify hotels: public domain or trademark protected? URL: http://condat.blogspot.com/2011/04/switzerland-use-of-stars-to-classify.html

5. The Law of Ukraine "On Tourism" No 324/95-v from 15.09.95 and On Amendments and Additions to the Law of Ukraine "On Tourism" from 18.11.03. Retrieved from https://zakon.rada.gov.ua/laws/show/324/95-\%D0\%B2\%D1\%80 (in Ukrainian).

6. Shishkina, L. (Ed.). (2004). DSTU 4269:2003. Tourist services; Hotel Classification, III. Kyiv: Derzhspozhyvstandart of Ukraine, 13 pp. (in Ukrainian).

7. Resolution of the Cabinet of Ministers of Ukraine (July 29, 2009, No. 803). Procedure for establishing categories for hotels and other objects intended for provision of temporary accommodation services (accommodation). Retrieved from https://zakon.rada.gov.ua/laws/show/803-2009-\%D0\%BF (in Ukrainian). 
8. Biletska, I. M. (2015). National features of organization of hotel business in the world hospitality industry. Effective economy, 1. Retrieved from http://www.economy.nayka.com.ua/?op=1\&z=3745 (in Ukrainian).

9. Grin'ko, T. V., \& Timar, I. V. (2014). The image of enterprises of the sphere of services: the essence of the notion and peculiarities of formation. Collection of scientific works of Cherkasy State Technological University. Series: Economic Sciences, 38(I), 127-133 (in Ukrainian).

10. Malskaya, M. P., \& Pandyak, I. G. (2012). Hotel business: theory and practice. 2nd ed. Kyiv: Center for Educational Literature, 472 pp. (in Ukrainian).

11. Pandyak, I. (2015). The history of categorization of hotel enterprises in Ukraine. Proceedings from Geography, Economics and Tourism: National and International Experience (pp. 146152). Lviv: Publishing Centre of Ivan Franko National University of Lviv (in Ukrainian).

12. Timar, I. V. (2016). Categorization of hotel business enterprises: domestic and world experience. Management of development, 3, 71-77 (in Ukrainian).

13. Tkachenko, T. (2005). Quality management of hotel services. Hospitality business, 4, 24-27 (in Ukrainian).

14. Fedorchenko, V. K., \& Minich, I. M. (1999). Hospitality: main indicators, assessment of service quality. Kyiv: KUTEP, 78 pp. (in Ukrainian).

Стаття: надійшла до редакиії 26.07.2019

доопращьована 15.09.2019

прийнята до друку 25.09.2019

\title{
КАТЕГОРИЗАЦІЯ СУБ'ЄКТІВ ГОТЕЛЬНОГО БІЗНЕСУ: СУЧАСНІ ПІДХОДИ ТА ТЕНДЕНЦІЇ У СВІТІ ТА В УКРАЇНІ
}

\author{
Ігор Пандяк \\ Львівський національний університет імені Івана Франка, \\ вул. П. Дорошенка, 41, 79007, м. Львів, Україна, \\ e-mail: pandyakig@ukr.net
}

Дослідження зосереджено на актуальності категоризації в управлінні якістю обслуговування у готельних підприємствах. Проаналізовано основні підходи до категоризації суб'єктів готельного бізнесу у світі та в Україні, акцентовано увагу на необхідності визначення ключових підходів щодо управління якістю підприємствами готельного бізнесу, проблем стандартизації та процесу категоризації, обгрунтовано напрямки їхнього вирішення в Україні.

Проаналізовано просторову організацію категоризованих готельних підприємств в Україні та визначено залежність їхньої частки та структури в категорії від туристичної привабливості регіонів. Суттєвий вплив на категоризацію мають міжнародні та українські готельні корпорації, чиїм підприємствам присвоєно середню та високу категорію.

Серед основних проблем категоризації в Україні: застарілі, які не відповідають сучасним вимогам щодо якості обслуговування нормативні акти; складна процедура категоризації; відсутність правового механізму впливу на готельні підприємства, які публічно декларують певну категорію без проходження процесу категоризації; нерівноцінні регуляторні вимоги щодо проходження категоризації суб'єктами готельного бізнесу різної правової форми, потенціалу, історичного стану будівлі; не сформована у більшості інвесторів, топ-менеджменту готельного бізнесу професійна свідомість, орієнтована на глобальні процеси.

Ключові слова: суб'єкти готельного бізнесу, категоризація, сертифікація, класифікація, стандарти, якість обслуговування, системи категоризації, нормативно-правове забезпечення. 